\title{
A Right to Care: Putting Care Ethics at the Heart of UK Reconciliation Legislation GEMMA MITCHELL ${ }^{1}$
}

\begin{abstract}
This article will examine how a right to care could be applied in the UK to better support people's ability to balance their paid work and caring responsibilities. I will argue that this would inject the ethic of care into the body of work-life balance legislation to better value caring relationships and carers. This is important because paid work is currently prioritised in this body of legislation. I will argue that better valuing caring labour is key to achieving transformative changes in both the workplace and the division of caring labour.
\end{abstract}

\section{INTRODUCTION}

Work-life balance issues have rarely been off the political agenda over the last two decades. There have been numerous legislative changes and amendments aiming to help employees reconcile paid work and caring work since New Labour first came to Government in 1997. In this article, I will argue that the various entitlements fail to provide the necessary support to those balancing paid work and care. This is because leave entitlements result in caring responsibilities being only momentarily prioritised; there is no provision for ongoing support or fundamental change to the workplace. I will argue that the lack on ongoing support reflects the persistent undervaluing of care work.

The original contribution of this paper will be considering how a right to care could be applied in the UK. In this regard, I will build on Busby's work developing a right to care

\footnotetext{
${ }^{1}$ I am thankful to Professor Andreas Stephan and the two anonymous reviewers for their feedback on earlier versions of this article.
} 
within the European Union (EU) legal order. The paper will demonstrate that a right to care could be used to promote important social goals, including challenging gender inequality. This would involve recognising care as a protected characteristic as well as introducing a duty of reasonable adjustment for carers. A right to care would modify and improve the current legislative approach to balancing paid work and caring responsibilities, by recognising that care is "central to our individual and collective well-being," drawing on the ethic of care literature. ${ }^{2}$

Firstly, I will outline the current legislative entitlements that aim to support those balancing their paid work and caring work. These were initially named family-friendly policies, but have since been renamed work-life balance policies, reflecting a change in focus away from solely supporting those with caring responsibilities. ${ }^{3}$ This body of law will be referred to as reconciliation legislation. This was a definition adopted by Busby and James, which avoids focusing entirely upon childcare and covers the wide variety of policies that deal with the perceived conflict between paid work and care. ${ }^{4}$ I will then identify why reconciliation legislation fails to provide carers the support they need; it fails to adequately value care work. The ethic of care will then be introduced and, drawing on James' work, I will show how basing the legislation on this would better value caring work. ${ }^{5}$ Next, Busby's proposal of a right to care at EU level is analysed. Finally, I examine the effect of applying a right to care in the UK as a way to introduce the ethic of care into the legislation. I will argue that this would justify transformative changes in recognition of the importance of care work.

\footnotetext{
${ }^{2}$ N. Busby A Right to Care? Unpaid Care Work in European Employment Law (Oxford University Press, 2011) 8.

${ }^{3}$ S. Macpherson 'Reconciling Employment and Family Care-Giving: A Gender Analysis of Current Challenges and Future Directions for UK Policy' in N. Busby and G. James Families, Care-giving and Paid Work: Challenging Labour Law in the 21st Century (Edward Elgar, 2011) 24.

${ }^{4}$ N. Busby and G. James Families, Care-giving and Paid Work: Challenging Labour Law in the 21st Century (Edward Elgar, 2011).

${ }^{5}$ G. James 'Family-friendly employment law (re)assessed: the potential of care ethics' (2016) 45 Industrial Law Journal 477.
} 


\section{UK RECONCILIATION LEGISLATION}

The first reconciliation entitlement made widely available was maternity leave, after the Pregnant Workers Directive 1992 was implemented, aiming to promote the health and safety of women as well as encourage equal treatment in the workplace. ${ }^{6}$ This made fourteen weeks of leave available to all employees. ${ }^{7}$ The New Labour Government extended maternity leave multiple times, partly to remove obstacles for women to engage in paid work. ${ }^{8}$ Twelve months of maternity leave is currently available to mothers who are employees, nine months of which is paid if certain eligibility requirements are met. ${ }^{9}$ During the first six weeks, new mothers can claim $90 \%$ of their wages. For the remaining 33 weeks, they are entitled to the low flat rate of statutory maternity pay, which is currently $£ 145.18$ a week, ${ }^{10}$ or if it is less, $90 \%$ of their earnings. This is available those who have been in the same employment for a continuous period of at least twenty-six weeks at the fourteenth week before the expected week of childbirth. ${ }^{11}$ However, with all reconciliation entitlements, individual employers can choose to pay more than the statutory minimum. Adoption leave was introduced in 2002 and due to amendments under the Children and Families Act 2014, now mirrors maternity leave. ${ }^{12}$ The only substantive difference is that if the child is being adopted by a couple, the leave can be taken by whichever parent is nominated, so it is gender neutral. ${ }^{13}$

\footnotetext{
${ }^{6}$ Directive 92/85/EEC.

${ }^{7}$ Trade Union Reform and Employment Rights Act 1993, Directive 92/85/EEC.

${ }^{8}$ Department of Trade and Industry Fairness at Work (Cm 3968, The Crown, 1998) [5.1]. See J. Conaghan

'Feminism and Labour Law: Contesting the Terrain' in A. Morris, T. O’Donnell Feminist Perspectives on Employment Law (Cavendish, 1999) 38.

${ }^{9}$ Social Security Contributions and Benefits Act 1992, s 164(2)(a).

${ }^{10}$ Correct as of March 2019.

${ }^{11}$ Social Security Contributions and Benefits Act 1992, s 164(2)(a).

12 Employment Act 2002.

${ }^{13}$ Paternity and Adoption Leave Regulations 2002, reg 2(1), (4).
} 
Maternity leave was first supplemented by parental leave, which gives anyone with parental responsibility an individual right to leave. ${ }^{14}$ This was implemented and improved as a result of EU Directives which aimed to "improve the reconciliation of work, private and family life for working parents and equality between men and women with regard to labour market opportunities and treatment at work." 15 UK employees are now entitled to eighteen weeks' of parental leave per child until the child's eighteenth birthday. ${ }^{16}$ This is dependent on them having at least one year's continuous employment. ${ }^{17}$ Parental leave has had limited impact on the workplace: only $11 \%$ of parents with a child under six reported taking leave in 2012. ${ }^{18}$ This reflects the minimalist way in which the UK have implemented the EU Parental Leave Directives, most obviously reflected in the lack of pay available and the inflexible nature of the entitlement, as leave can only be taken in blocks of a week. ${ }^{19}$

Emergency leave was also introduced. ${ }^{20}$ This is available to a wide variety of potential carers. ${ }^{21}$ However, as the name suggests, emergency leave is available for only a very limited period of time. ${ }^{22}$ Therefore, it does not aim to provide ongoing support to balance paid work and caring responsibilities.

The aims of UK reconciliation legislation began to change in 2002. In response to criticism of family-friendly policies, New Labour renamed them work-life balance policies

\footnotetext{
14 The Maternity and Parental Leave etc. Regulations 1999, reg 14.

${ }^{15}$ Parental Leave Directive 2010/18/EC, (8). This was implemented by Parental Leave (EU Directive) Regulations 2013 and preceded by Parental Leave Directive 96/34/EC.

${ }^{16} \operatorname{Reg} 14(1)$.

${ }^{17}$ The Maternity and Parental Leave etc. Regulations 1999, reg 14.

${ }^{18}$ S. Tipping, J. Chanfreau, J. Perry, C. Tait The Fourth Work-Life Balance Employee Survey (Department for Business, Innovation and Skills, 2012) 6.

19 96/34/EC and 2010/18/EC. However, note again that some employers might choose to confer more generous entitlements. Furthermore, employers can make the leave available flexibly.

${ }^{20}$ Employment Relations Act 1999 s 8.

${ }^{21}$ Employment Rights Act 1996, s 57A (3).

${ }^{22}$ Qua v John Ford Morrison Solicitors [2003] I.C.R. 482 [21].
} 
from 2001-10. ${ }^{23}$ This signalled "the desire both to include those without care responsibility and to find new ways of managing increasingly diverse workforces." ${ }^{24}$ Nonetheless, the legislation continued to focus upon parents. For example, the right to request flexible working was introduced for parents. ${ }^{25}$ The Coalition Government (2010-15) since extended this to all employees who meet certain eligibility requirements. ${ }^{26}$ Employers must "deal with the application in a reasonable manner," 27 but can reject requests on a broad range of business grounds, including the burden of additional costs and detrimental impact on quality or performance. ${ }^{28}$ If employers are unsympathetic to employees' needs, they can easily reject requests, "and the employment tribunals have very little powers of enforcement so long as the procedure is followed." 29 Therefore, the right to request flexible working is a weak right because it does not entitle carers to work flexibly.

This first section has shown how reconciliation legislation initially focused on mothers' balancing paid work and caring labour, partly to encourage women's participation in the paid workplace. Even the right to request flexible working, which was part of the new focus on work-life balance, still initially focused on parents. This would have primarily benefitted women, who perform more part-time work because of their continued association with caring labour; $41 \%$ of women work part-time compared to $12 \%$ of men. ${ }^{30}$ Therefore, even this legislation was arguably directed at mothers. Yet women continue to face particular

\footnotetext{
${ }^{23}$ S. Macpherson 'Reconciling Employment and Family Care-Giving' (n 3$) 24$.

${ }^{24}$ J. Lewis Work Family Balance, Gender and Policy (Edward Elgar, 2009) 1.

${ }^{25}$ Employment Act 2002 s 47.

${ }^{26}$ Children and Families Act 2014, s 131.

${ }^{27}$ Ibid. s 132(2) and (3).

${ }^{28}$ Employment Rights Act 1996 s 80G(1)(b).

${ }^{29}$ James G, 'The Work and Families Act 2006: Legislation to Improve Choice and flexibility?' (2006) 35 Industrial Law Journal 272, 277.

${ }^{30}$ Office for National Statistics Annual Survey of Hours and Earnings: 2016 Provisional Results. (Office for National Statistics, 2016) 8.
} 
disadvantages in the workplace. Their experience of paid work remains different to men's, as will be explored in the next section.

\section{A. Women's different workplace participation}

Women's disadvantaged position in the workplace is demonstrated in the persistent gender pay gap. This is currently the lowest on record between full-time employees, at $9.1 \% .{ }^{31}$ However, between all employees, it widened last year to $18.4 \% .^{32}$ Although already in existence, the pay gap widens after 24 , which corresponds with the time many women become mothers; the average age of first-time mothers is 28.8 years. ${ }^{33}$ This is because motherhood changes employment patterns as women "typically interrupt or drastically reduce their employment," for example working part-time. ${ }^{34}$ In contrast, research suggests that fatherhood has little effect on men's paid working hours in the UK. ${ }^{35}$

Women may scale back employment for a number of reasons. One is discrimination; recent research suggests that as many as 54,000 pregnant women a year were dismissed, made redundant, or "treated so poorly they felt they had to leave their job." 36 The current Government has agreed to review the maternity discrimination legislation and consolidate it, to tackle this discrimination. ${ }^{37}$ It is positive that the Government has recognised the problem.

\footnotetext{
${ }^{31}$ Office for National Statistics Annual Survey of Hours and Earnings: 2017 provisional and 2016 revised results (Office for National Statistics, 2017) 2.

${ }^{32}$ Ibid. 12.

${ }^{33}$ Office for National Statistics Understanding the gender pay gap in the UK (Office for National Statistics, 2018) 15; Office for National Statistics Births by parents' characteristics in England and Wales: 2016 (Office for National Statistics, 2017) 2.

${ }^{34}$ P. Schober 'The Parenthood Effect on Gender Inequality: Explaining the Change in Paid and Domestic Work When British Couples Become Parents' (2013) 29 European Sociological Review 74, 74.

${ }^{35}$ M. Costa Dias, W. Elming and R. Joyce. The Gender Wage Gap: IFS Briefing Note BN186 (The Institute for Fiscal Studies, 2016) 13; E. Dermott Intimate Fatherhood: A Sociological Analysis (Abingdon: Routledge, 2008) 629; S. Sheldon and R. Collier Fragmenting Fatherhood: A Socio-Legal Study (Oxford: Hart, 2008$) 129$. ${ }^{36}$ Department for Business, Innovation and Skills and the Equality and Human Rights Commission Pregnancy and Maternity-Related Discrimination and Disadvantage: Summary of Key Findings (London: Crown, 2016) 6.

${ }^{37}$ Her Majesty's Government Good Work: A response to the Taylor Review (Crown, 2018) 35.
} 
However, it is unlikely to be solved by simply consolidating the legislation; the vast numbers of women being discriminated against every year highlights that a more fundamental change is required.

Women's lesser earning power, because they are often paid less, is another reason they may scale back their work. It is typically more financially viable for women to cut down their paid work commitments to provide care when necessary, as men's wages are likely to be more vital to families' survival. Motherhood causes ongoing disadvantage to women in the workplace, evidenced in the gradual widening of the pay gap after childbirth. ${ }^{38}$

Another disadvantage women face in the workplace is that the nature of women's work is different to men's; they are disproportionately associated with precarious work. ${ }^{39}$ This work is associated with "low wages, few benefits, the absence of collective representation, and little job security." 40 Those in precarious work are some of the most vulnerable and lowly paid people in the workforce. There has been growing awareness of this, culminating in the Government asking the Taylor review to examine the idea of good work. ${ }^{41}$ However, both the review and the Government's response fell significantly short of offering any fundamental change for those in precarious work, because the review was 'blunted by a high degree of satisfaction with the workings of the current labour market. ${ }^{, 42}$

\footnotetext{
${ }^{38}$ M. Costa Dias, W. Elming and R. Joyce. The Gender Wage Gap (n 35) 12.

${ }^{39}$ Alongside "racial and ethnic minorities, disabled workers, and other groups with marginal social power." See K. Rittich 'Rights, Risk and Reward: Governance Norms in the International Order and the Problem of Precarious Work' in J. Fudge and R. Owens (eds) Precarious Work, Women and the New Economy: The Challenge to Legal Norms (Oxford: Hart, 2006) 49.

${ }^{40}$ Ibid. 12.

${ }^{41}$ Her Majesty’s Government Good Work (n 37).

${ }^{42}$ K. Bales, A. Bogg, T. Novitz 'Voice' and 'Choice' in Modern Working Practices: Problems with the Taylor Review’ (2018) 47 Industrial Law Journal 46, 49.
} 
Women and men continue to participate in the workplace on unequal terms. Furthermore, motherhood continues to be the cause of many of these disadvantages. Increasingly Governments have recognised that workplace equality cannot be achieved by focusing upon women alone; the reconciliation of paid work and caring labour is not solely an issue for mothers. Indeed, as the next section will show, the work-life balance policies marked another change of legislative focus; encouraging father's caring role.

\section{CHANGING FOCUS OF RECONCILIATION LEGISLATION}

The first entitlement aiming to encourage fathers to provide care was two weeks of ordinary paternity leave, subject to eligibility requirements. ${ }^{43}$ The rate of ordinary paternity pay is the same as statutory maternity pay (£145.18 a week). New Labour suggested that ordinary paternity leave recognised fathers' caring role was “as important as increasing women's ability to participate in the labour market." ${ }^{44}$ The leave is available not only to fathers, but to mothers' or adopters' spouses, partners or civil partners who expect to have the main responsibility (apart from the mother) for childcare. ${ }^{45}$ Due to the focus on encouraging men to care, this article will refer to fathers' uptake of leave, despite the entitlements being available to this wider category of carers. ${ }^{46}$

$91 \%$ of fathers take some leave when their child is born. ${ }^{47}$ This shows that men want to participate in this period of childcare. The high take up also evidences that taking some

\footnotetext{
${ }^{43}$ Employment Act 2002, s 1. This amended the Employment Rights Act 1996 to introduce ordinary paternity leave (S 80A). The Paternity and Adoption Leave Regulations 2002 introduces the detailed provisions.

${ }^{44}$ Department for Trade and Industry Work and Parents: Competitiveness and Choice (Cmnd 5005) (London: Crown, 2000) 14. G. James 'Work and Parents: Competitiveness and Choice' Green Paper (Cmnd 5005 December 2000): A Policy to Promote Parenting / Workplace Harmony?’ (2001) 2 Web Journal of Current Legal Issues.

45 The Paternity and Adoption Leave Regulations 2002, reg 4(2)(b).

${ }^{46}$ Ibid. reg 4(2)(b)(ii) and(c)(ii) and reg 8(2)(b)-(c). The Shared Parental Leave Regulations 2014, reg 3(1).

${ }^{47}$ J. Chanfreu, S. Gowland, Z, Lancaster, E. Poole, S. Tipping, M. Toomse Maternity and Paternity Rights Survey and Women Returners Survey 2009/10 (Department for Work and Pensions, 2011) 151.
} 
leave to care for a child has become the norm. However, two weeks of leave gives fathers the briefest insight into caring and merely "perpetuates the assumption that the mother is (and should be) the primary carer of the child." ${ }^{48}$ The legislation confirms this; the leave is to "care for the child and support the mother." 49 Therefore, although fathers have taken ordinary paternity leave, it has not encouraged or achieved long-term changes in the division of childcare.

New Labour made more leave available as additional paternity leave, which the Coalition Government (2010-15) replaced with shared parental leave, making 50 weeks of maternity or adoption leave transferable to fathers and mothers' partners. ${ }^{50} 38$ weeks of shared parental pay is available at $£ 145.18$; the final twelve weeks are unpaid. ${ }^{51}$ Shared parental leave aimed to create a society where work and family complement one another by challenging the assumption that mothers should be primary caregivers. ${ }^{52}$ This was to be achieved by enabling "working fathers to take a more active role in caring for their children and [for] working parents to share the care of their children.. ${ }^{, 53}$ Encouraging men to spend more time caring, was also linked to women maintaining a strong attachment to the workplace and therefore reducing 'the 'gender penalty' that women suffer from taking time out of the workplace with their children." 54

\footnotetext{
${ }^{48}$ G. James 'All That Glitters is not gold: Labour's Latest Family-Friendly Offerings' (2003) 3 Web Journal of Current Legal Issues.

49 The Paternity and Adoption Leave Regulations 2002, reg 4(1).

${ }^{50}$ The Maternity and Adoption Leave (Curtailment of Statutory Rights of Leave) Regulations 2014, regs 6(2)(a) and $10(2)(b)$

${ }^{51}$ The Statutory Shared Parental Pay Regulations 2014, reg 40(1).

${ }^{52}$ Department for Business Innovation and Skills Consultation on Modern Workplaces: Flexible Parental Leave, Flexible Working, Working Time Regulations, Equal Pay (London: Crown, 2011) 14-15.

${ }^{53}$ Department for Business, Innovation and Skills Modern Workplaces Consultation: Government Response to Flexible Parental Leave Proposals (London: Crown, 2012) 3.

${ }^{54}$ Ibid. 7.
} 
Shared parental leave has failed to achieve these ambitious aims. It has long been recognised that the effectiveness of leave schemes is dependent upon men actually using their entitlement. ${ }^{55}$ Yet the uptake of shared parental leave has been low; only $2 \%$ of eligible parents have taken any. ${ }^{56}$ Therefore, shared parental leave has achieved no transformative change in the division of caring labour or in the paid workplace in the UK. Care work remains highly gendered as women "disproportionately bear the care burden." 57 As noted, women also continue to be disadvantaged within the paid workplace. In the next section, I will argue that this is primarily because reconciliation legislation focuses upon paid work and fails to acknowledge the importance of caring work.

\section{THE LEGISLATION'S UNDERVALUING OF CARE WORK}

The undervaluing of care work has been a constant criticism since maternity leave was first implemented. Over two decades ago, Fredman noted that the maternity leave legislation's "focus is entirely workplace orientated as it assumes that the main issue is a women's inability to do her work, thereby ignoring the positive medical and social reasons for leave." 58 In this section, I will highlight the three main current manifestations of this criticism. Firstly, the low levels of payment for mothers' caring work, which particularly undervalues caring labour provided by non-employees. Secondly, I will argue that despite the problems with the support provided to mothers, their caring role remains privileged compared to other carers. Fathers' caring roles are undervalued and their paid work commitments prioritised in the body of legislation, reinforcing traditional ideas of the heterosexual family. Fathers in turn

\footnotetext{
${ }^{55}$ S. Fredman Women and the Law (Oxford University Press, 1997) 219.

${ }^{56}$ Department for Business, Energy \& Industrial Strategy 2018 Press release New 'Share the joy' campaign promotes shared parental leave rights for parents $<$ https://www.gov.uk/government/news/new-share-the-joy-campaign-promotes-shared-parental-leave-rights-forparents $>$ accessed 20/02/2018.

57 J. Herring Caring and the Law (Hart, 2013) 34.

${ }^{58}$ S. Fredman 'A Difference with Distinction: Pregnancy and Parenthood Reassessed' (1994) 110 Law Quarterly Review 106, 113.
} 
are eligible for more support than those caring for adults, or those without parental responsibility who are caring for children. Finally, I will demonstrate how the priority given to paid work means that reconciliation legislation fails to challenge the standard worker model.

\section{A. Low levels of payment for mothers taking leave}

Fredman noted that "the central manifestation of the low priority given to maternity and parenthood...is the low level of statutory maternity pay." ${ }^{59}$ Statutory maternity pay is the most generous entitlement, but only the first six weeks are paid at an income-related level, paid at $90 \%$ of the mother's income. This period has remained the same since the Pregnant Workers Directive was implemented. ${ }^{60}$ All other leave entitlements, including the next 33 weeks of maternity pay, are paid at the low flat rate of $£ 145.18$ or $90 \%$ of their income if this is less. Although payment demonstrates that childcare is a public concern, the low level reflects how undervalued childcare remains. The "pitiful" low flat rate is less than the minimum wage. ${ }^{61}$ This clearly demonstrates that caring labour is considered to be of less value than paid work. Furthermore, as mothers alone are entitled to income-related pay, the legislation "draws an unnecessary and arbitrary distinction between maternity and paternity leave, thereby according a lower value to paternal care and suggesting that it is a secondary or supplementary right." 62

The final twelve weeks of maternity leave are unpaid, as is parental leave. The total lack of pay undermines parents' access to these periods of leave. This is reflected in the low

\footnotetext{
${ }^{59}$ S. Fredman Women and the Law (n 55) 199.

60 92/85/EEC.

${ }^{61}$ G. James The Legal Regulation of Pregnancy and Parenting in the Labour Market (Routledge, 2009$) 43$.

${ }^{62}$ M. Weldon-Johns 'The Additional Paternity Leave Regulations 2010: A New Dawn or More 'Sound-bite' Legislation' (2011) 33 Journal of Social Welfare and Family Law 25, 28.
} 
uptake of parental leave as well as the average length of maternity leave actually taken being 39 weeks. ${ }^{63}$ The unpaid final twelve weeks remain less attractive to mothers. ${ }^{64}$ The low level of payment may also undermine the take up of other provisions, including keep in touch days. $^{65}$

The importance of paid work is also emphasised by the minimum eligibility requirements. Although all employees are entitled to maternity leave as a day one right, statutory maternity pay is only available to employees who have been employed for twenty-six weeks. ${ }^{66}$ Those who do not meet these requirements may be able to access maternity allowance, which is paid at $£ 145.18$ a week, or $90 \%$ of their income if that is lower. ${ }^{67}$ Eligibility is dependent upon being "engaged in employment or as an employed or self-employed earner" for any part of twenty-six weeks of the last sixty-six weeks. ${ }^{68}$ They also must have been earning over the maternity allowance threshold, which is currently at least $£ 30$ a week, over any thirteen week period. ${ }^{69}$ Maternity allowance does recognise the caring roles of non-employees and grants some support to workers after childbirth, including those in precarious work, who are denied much of the protection of labour law. Yet this support is more limited than the support available for employees as there is no income related pay available. Therefore, the level of financial support mothers receive is determined by their commitment to the workplace. The work of caring for a newborn child is not always deemed equally important, even though each parent is performing life sustaining and labour intensive work. Furthermore, $11 \%$ of the

\footnotetext{
${ }^{63}$ J. Chanfreau et al Maternity and Paternity Rights and Women Returners Survey 2009/2010 (n 47) 30.

${ }^{64}$ M. O’Brien, A. Koslowski 'United Kingdom' in A. Koslowski, S. Blum, P. Moss 12th International Review of Leave Policies and Related Research 2016 (International Network on Leave Polies and Research, 2016$) 365$.

${ }^{65}$ See G. James 'Enjoy your leave but "keep in touch": Help to maintain parent/workplace relationships' (2007)

36 Industrial Law Journal 313.

${ }^{66}$ Social Security Contributions and Benefits Act 1992, s 164(2)(a).

${ }^{67}$ Ibid. s 35.

${ }^{68}$ Ibid. s 35(1)(b).

${ }^{69}$ Social Security (Maternity Allowance) (Earnings) Regulations 2000, reg 5(a).
} 
most disadvantaged workers who were in paid work before childbirth did not even receive this lower level of support. ${ }^{70}$ This lack of pay undermines their recovery time and their chance to provide childcare.

These problems highlight how much caring labour is undervalued, even in the privileged mother-child caring relationship, where special treatment is required not least for the health and safety of both mother and child. ${ }^{71}$ However, there is at least support for pregnant women and new mothers who are workers or do not meet the minimum eligibility requirements. Those providing care in any other relationship, or at another time, do not receive even this limited level of support for their caring work.

\section{B. Undervaluing of care provided by others}

Ordinary paternity leave, shared parental leave and the corresponding pay are only available to employees who have been employed for twenty-six weeks by their current employer. This is the leave available to men. Therefore, the legislation reinforces the traditional notion that paid work is the most important activity for men. Indeed, their participation in childcare is reliant upon conformance and commitment to traditional employment models, as nonemployees are excluded from any support. Reconciliation entitlements fail to recognise the importance of all caring relationships and the work they entail, instead prioritising paid work.

Furthermore, shared parental leave reinforces mothers' primary caring role in other ways. The legislation appears to challenge the traditional ideas of the heterosexual family reflected in earlier reconciliation legislation (the long period of leave reserved for the mother and the

\footnotetext{
${ }^{70}$ M. O’Brien, A. Koslowski ‘United Kingdom’ (n 64) 366.

${ }^{71}$ N. Busby A Right to Care? (n 2) 43. 
short two week period provided for fathers), but this is merely superficial. Fathers can only access shared parental leave if the mother consents, suggesting mothers are the gatekeepers of fathers' access to leave. ${ }^{72}$ Furthermore, in addition to the eligibility requirements, fathers' eligibility is also dependent upon the mother's workplace commitment, who must have "been engaged in employment as an employed or self-employed earner for any part of the week in the case of at least 26 of the 66 weeks immediately preceding the calculation week," to be able to transfer her maternity leave. ${ }^{73}$ The different eligibility requirements for each parent, along with 'confusing and cumbersome' notice requirements, make taking shared parental leave unnecessarily complex. ${ }^{74}$ This risks that many individuals and families will miss out on taking this leave, even if eligible.

It is also notable how support for dependents decreases as they get older. The most support is available in the child's first year, when paid leave is available. After that, until a child is 18 , parental leave is available to those with parental responsibility. However, once a dependent becomes an adult, there is no entitlement to any form of leave. Those without parental responsibility who are caring for children are in the same position, including the predicted 2 million grandparents that "have given up work, reduced their hours or have taken time off work to help families who cannot afford childcare costs." 75 These carers can only access emergency leave and the right to request flexible working. Making all employees eligible for the right to request flexible working has also weakened this right for carers. The extension problematically reinforces the invisibility of caregiving and suggests it is

\footnotetext{
72 The Shared Parental Leave Regulations 2014, reg 8(3)(b)(iii).

73 The Shared Parental Leave Regulations 2014, regs 5(2)(a), 5(3)(a) and 36(1)(a).

${ }^{74}$ G. James 'Family-friendly employment law (re)assessed' (n 5) 484.

${ }^{75}$ Chancellor announces major new extension of shared parental leave and pay to working grandparents https://www.gov.uk/government/news/chancellor-announces-major-new-extension-of-shared-parental-leaveand-pay-to-working-grandparents accessed 18.04.2016.
} 
comparable to hobbies and other past-times, which misrepresents and undervalues the lifesustaining and everyday nature of care work. ${ }^{76}$ Therefore, the body of UK reconciliation legislation particularly devalues the care work provided by these carers.

Although mothers' caring role is undervalued and underpaid, this section has shown that care work provided by fathers is even more so. Reconciliation legislation instead emphasises their role in paid work. However, fathers in turn are provided with more protection than other carers. In the next section, I will highlight the third and final way in which care work has been undervalued in comparison to paid work; reconciliation legislation remains centred around the standard worker model.

\section{Fails to challenge the standard worker model}

Reconciliation legislation itself does "not touch the essence of labour law." 77 Instead, it only intervenes at the margins. Leave entitlements result in caring responsibilities being only momentarily prioritised; upon return to the workplace, they again become secondary. The standard worker model remains unchallenged as caring relationships can only impact upon the workplace in specific circumstances. Outside of these situations, the interdependent nature of caring relationships and paid work is obscured, despite the legislation demonstrating how intertwined they are. ${ }^{78}$ Indeed, Busby argues that even the terminology provides little reassurance of long term change; family-friendly or work-life legislation suggests that all other labour policies are inherently family or even life unfriendly. ${ }^{79}$

\footnotetext{
${ }^{76}$ A. Masselot 'Gender Implications of the Right to Request Flexible Working Arrangements: Raising Pigs and Children in New Zealand' (2015) 39 New Zealand Journal of Employment Relations 59, 63.

77 J. Conaghan 'Feminism and Labour Law' (n 8) 14.

78 J. Conaghan 'Women, Work and Family: A British Revolution?' in J. Conaghan, R. Fischl, K. Klare Labour Law in an Era of Globalization (2002, Oxford University Press) 72.

${ }^{79}$ N. Busby A Right to Care? (n 2) 49. 
The standard worker model is further reflected in the lack of flexibility. All leave entitlements are only available in weeklong blocks. This was justified in the House of Commons debates on shared parental leave because part-time leave is too complex to calculate as "payroll systems operate on that kind of weekly basis." 80 This argument is not only unconvincing because hourly wages can be calculated, the focus upon reducing employers' burdens also demonstrates the prioritisation of paid work. ${ }^{81}$ The lack of flexibility merely confirms that caring relationships can only be maintained in ways which do not challenge the standard worker model. ${ }^{82}$

The only legislative intervention which provides any hope of long-term change is the right to request flexible working. However, not only is this a weak right because it does not entitle carers to work flexibly, it fails to challenge the negative consequences of part-time work. This often includes an immediate and significant reduction in wages. ${ }^{83}$ Therefore, the legislation fails to provide the necessary support to those who do not conform to the standard worker model. Furthermore, if a request is accepted, it leads to a permanent change in the contract. ${ }^{84}$ This overlooks the complex nature of care work. Tronto identifies different stages of the care process; recognising the need for care; taking responsibility to meet those care needs; the direct care work; and recognising how the care has been received. ${ }^{85}$ At each stage, carers could encounter problems, resulting in incomplete or inadequate care. Employees need

\footnotetext{
${ }^{80}$ Jo Swinson, the then Minister for Employment Relations and Consumer Affairs in the Department for Business, Innovation and Skills and the Women and Equalities Minister. Children and Families Bill Deb $23^{\text {rd }}$ April 2013, 17th sitting, col. 713.

${ }^{81}$ Lord Stevenson of Balmacara, Labour Lord and Shadow Spokesperson for Business, Innovation and Skills. HL Children and Families Bill Deb $20^{\text {th }}$ November 2013, twelfth day, col. GC423.

${ }^{82}$ E. Carricolo Di Torella 'New Labour, New Dads - The Impact of Family-Friendly Legislation on Fathers' (2007) 36 Industrial Law Journal 318, 325 and M. Weldon-Johns 'The Additional Paternity Leave Regulations 2010' (n 62) 27-28.

${ }^{83}$ C. Lyonette, B. Baldauf, H. Behle Quality Part-time Work: A Review of the Evidence (Government Equalities Office, 2010) 8-9.

${ }^{84}$ Employment Rights Act 1996, s 80F(1).

${ }^{85}$ J. Tronto Caring Democracy: Markets, Equality, and Justice (New York University Press, 2013) 22-23.
} 
flexibility when providing care to deal with the multitude of events that could happen at the different stages. Yet the permanent change to a contract disregards this, instead prioritising the workplaces' needs for consistency and reliability. These problems highlight Conaghan's concern that reconciliation legislation intervenes at the margins of labour law, rather than creating the fundamental changes needed to challenge the standard worker model. ${ }^{86}$

Therefore, despite the numerous legislative improvements made to the body of reconciliation legislation, countless problems remain for those providing care. These problems reflect the undervaluing of care work and prioritisation of paid work within the legislation. Overcoming these problems would require better valuing of caring relationships within the legislation. In that regard, I will examine the ethic of care.

\section{THE ETHIC OF CARE}

The ethic of care has been a fundamental feminist concern since Gilligan's breakthrough work in the 1980s, In a Different Voice: Psychological Theory and Women's Development. ${ }^{87}$ Gilligan highlighted two different moral orientations. The first focused upon justice, which seeks a fair conclusion between competing rights and protects equality and freedom. ${ }^{88}$ According to Gilligan's research, this approach is associated with men and thus underpins the public sphere. In contrast, the ethic of care, more associated with women and the private sphere, recognises intertwined relationships, fostering social need and co-operation, challenging traditional liberal ideas of autonomy. ${ }^{89}$ Later research has challenged this gendered division, as Gilligan's work failed to consider how other factors such as class, race

\footnotetext{
${ }^{86}$ J. Conaghan 'Feminism and Labour Law' (n 8) 14.

87 C. Gilligan (Harvard University Press, 1982).

${ }^{88}$ V. Held The Ethics of Care: Personal, Political and Global (Oxford University Press, 2005) 15.

${ }^{89}$ Ibid. 15.
} 
or socialisation affect people's moral orientations. ${ }^{90}$ By failing to address these other factors, Gilligan problematically reinforces gender role assumptions. ${ }^{91}$ Furthermore, the division between the two moral orientations has been increasingly challenged, ${ }^{92}$ partly because feminists have noted that at the heart of justice is "a voice of responsibility, care, and concern for others." ${ }^{93}$ Nonetheless, the ethic of care has developed into a normative theory based on the universal need for care; it is not just the obvious times of childhood, old age, illness and disability when people are dependent, but every day. ${ }^{94}$ It recognises that care work is important because it is life-sustaining. ${ }^{95}$

Although care has traditionally been considered a concern of the private sphere, increasingly it has been argued that the care ethic should be deployed in the public sphere. Tronto argues that the universal need for care necessitates that politics becomes 'much more focused upon care responsibilities: their nature, their allocation, and their fulfilment. ${ }^{96}$ She argues that this is necessary to achieve a democratic and equal society. ${ }^{97}$ Indeed, caring relationships require support in both the public and private spheres to achieve justice. As Noddings explains, "those that care about others in the justice sense must keep in mind that the objective is to ensure that caring actually occurs." 98 This is because "unless there is caring

\footnotetext{
90 J. Tronto Moral Boundaries: A Political Argument for an Ethic of Care (Routledge, 1993) 82-9.

${ }^{91}$ G. James 'Family-friendly employment law (re)assessed' (n 5) 494.

92 O. Flanagan, K. Jackson 'Justice, Care, and Gender: The Kohlberg-Gilligan Debate Revisited' (1987) 97 Ethics 622, 624-6.

93 S. Okin 'Reason and Feeling in Thinking About Justice' (1989) 99 Ethics 229, 230. See further O. Flanagan, K. Jackson 'Justice, Care, and Gender' (n 92) 636 and 624; N. Noddings Starting at Home: Caring and Social Policy (Cambridge University Press, 2002) 24.

94 J. Herring Caring and the Law (n 57) 2.

${ }^{95}$ M. Glucksmann 'Why "Work"? Gender and the "Total Social Organisation of Labour"” (1995) 2 Gender, Work and Organisation 63, 70.

96 J. Tronto Caring Democracy (n 85) 30.

97 J. Tronto Caring Democracy (n 85) 29.

${ }^{98}$ N. Noddings Starting at Home (n 93) 24.
} 
there is no possibility for justice, ${ }^{99}$ as the most basic human right, the right to life, will be undermined. ${ }^{100}$

James has convincingly argued that the ethic of care should be applied to reconciliation legislation to "help promote a framework that better reflects the interdependence of care and better challenges gendered constructions of care-work and labour market participation." ${ }^{101}$ She notes that this would lead to two main changes to reconciliation legislation. Firstly, it could promote men's caring role. ${ }^{102}$ This is because the ethic of care recognises that "we are all responsible for and all capable of providing care for others," justifying the redistribution of caring responsibilities between men and women. ${ }^{103}$ Secondly, an injection of care would better incorporate "the needs and perspectives of those receiving care." 104 This would require that legislation recognised the ongoing commitment of caring relationships and challenging, for example, the myopic focus upon the child's first year. $^{105}$

In addition, I argue there are two other positive changes an ethic of care would justify. Firstly, leave would be income-related in recognition that care work is equally as important as paid work. Secondly, it would ensure that the legislation recognised that caring relationships are needed to "lead successful and fulfilling lives." 106 This would challenge the

\footnotetext{
99 J. Herring Caring and the Law (n 57) 68.

100 This is protected in countless human rights treaties. See for example The European Convention on Human Rights, art. 2. Universal Declaration of Human Right, art. 3.

${ }^{101}$ G. James 'Family-friendly employment law (re)assessed' (n 5) 478.

102 Ibid. 496.

103 Ibid. 497.

104 Ibid. 499.

105 Ibid. 497.

${ }^{106}$ N. Busby A Right to Care? (n 2) 46.
} 
legislative focus upon workplace needs. ${ }^{107}$ Instead, the legislation would focus upon individuals' needs for support in their caring relationships.

Therefore, the ethic of care could solve a number of the problems with UK reconciliation legislation. In the next section, I will consider one way that an ethic of care could be injected into this body of legislation; through the introduction of a right to care alongside paid employment.

\section{A RIGHT TO CARE}

Busby's development of a right to care in the EU legal order is based upon the ethic of care and the understanding that caring labour is "central to our individual and collective wellbeing." 108 The basis of her argument is that those providing care should be treated as equally productive and valuable members of society as non-carers. As a right is something "we view as being central to our individual and collective well-being," this would elevate the status of caring labour. ${ }^{109}$ Indeed, it would acknowledge that caring labour is of fundamental importance to all people's lives. The right to care would also promote gender equality by better valuing women's work, both paid and unpaid, as well as contribute "towards the normalization of atypical work arrangements." 110

Busby suggests that a right to care would create an overarching evaluative space to determine how carers' wellbeing could be promoted. She draws upon Sen's work on the capabilities approach to achieve this. ${ }^{111}$ The capabilities approach is an account of minimum

\footnotetext{
107 S. Fredman 'A Difference with Distinction' (n 58) 113.

108 N. Busby A Right to Care? (n 2) 8.

${ }^{109}$ Ibid. 8.

${ }^{110}$ Ibid. 182.

111 Ibid. 37.
} 
core social entitlements which measures the wellbeing of people by the level of capabilities each individual has. Sen explains these are the things a person needs to "lead the kind of lives they value - and have reason to value."112 Sen's capabilities approach provides “an 'evaluative space' within which judgements about individual well-being and social policies can be made."113 The evaluative space created by a right to care would create the space to consider if capabilities were being undermined. Furthermore, it would highlight how the workplace "present[s] barriers to the achievement of an individual's potential," emphasising carers' needs for ongoing support. ${ }^{114}$

\section{A. What would a right to care look like?}

Busby argues that a right to care should firstly "be observant of, but not reliant on preexisting anti-sex discrimination legislation." 115 This requires that the status of carer is recognised as a protected characteristic in the anti-discrimination laws. ${ }^{116}$ Horton argues this would benefit carers by recognising caring relationships as an "essential feature...of what it is to be human," as important as being able to "live according to their sexual orientation, or their religion." ${ }^{117}$ This would also provide a clear message to employers; carers must be accommodated and protected in the workplace. Yet protection from direct discrimination is individualised; the law is only used to remedy limited instances of discrimination rather than challenge the workplace model which perpetuates this. Therefore, the standard worker model remains valorised. ${ }^{118}$

\footnotetext{
112 A. Sen Development as Freedom (Oxford University Press, 1999) 18.

${ }^{113}$ N. Busby A Right to Care? (n 2) 37-38.

114 Ibid. 38.

115 Ibid. 182.

116 Ibid. 182.

${ }^{117}$ R. Horton 'Care-Giving and Reasonable Adjustment in the UK' in N. Busby and G. James Families, CareGiving and Paid Work: Challenging Labour Law in the 21 ${ }^{\text {st }}$ Century (Edward Elgar, 2011) 146

${ }^{118}$ O. Smith 'Reconciling Care-Giving and Work in Ireland: The Contribution of Protection Against Family Status Discrimination' in N. Busby and G. James Families, Care-Giving and Paid Work: Challenging Labour Law in the $21^{\text {st }}$ Century (Edward Elgar, 2011) 162.
} 
Indirect discrimination could be more transformative. Although this protection also requires an individual to bring a claim, this would create "general anticipatory duties to dismantle obstacles of perception and to change workplace norms." ${ }^{119}$ Protection against indirect discrimination could therefore challenge the idealised norm of a worker without caring responsibilities. Yet this will not solve all carers' issues in the workplace. Protection is weakened by the complexity of the legislation, particularly with "defining the appropriate pool of comparison and in determining the appropriate margin of difference." ${ }^{\prime 20}$ Furthermore, indirect discrimination can be justified if it is a "proportionate means of achieving a legitimate aim." ${ }^{121}$ These issues highlight that although protecting carers from both direct and indirect discrimination would be an important step towards promoting carers' ability to perform in the paid workplace, more would be needed.

\section{B. Duty of reasonable adjustment}

To complement the recognition of carers as a protected characteristic, Busby suggests that a right to care requires a reflexive right. ${ }^{122}$ This would encourage trade unions or other workplace bodies to self-regulate and adapt a more generous right to care specifically tailored to each workplace.

\footnotetext{
${ }^{119}$ C. O'Brien 'Confronting the Care Penalty: The Case for Extending Reasonable Adjustment Rights Along the Disability/Care Continuum' (2012) 34 Journal of Social Welfare and Family Law 5, 20.

${ }^{120}$ S. Fredman Discrimination Law ( $2^{\text {nd }}$ ed, Oxford University Press, 2011) 185.

${ }^{121}$ Equality Act 2010, s 19(2)(d).

${ }^{122}$ N. Busby A Right to Care? (n 2) 182.
} 
In this regard, Busby considers the UK duty of reasonable adjustment contained in the Equality Act 2010. ${ }^{123}$ This imposes a duty on employers to make a reasonable adjustment in three circumstances; the first two are where either a "physical feature" or a "provision, criterion or practice of [the employers] puts a disabled person at a substantial disadvantage...in comparison with persons who are not disabled."124 Thirdly, an employer must take reasonable steps to provide an auxiliary aid to a disabled employee if not providing one would put them "at a substantial disadvantage in relation to a relevant matter in comparison with persons who are not disabled." ${ }^{125}$ A similar provision has also been codified in EU law (renamed as reasonable accommodation), which requires "a person with a disability to have access to, participate in, or advance in employment, or to undergo training, unless such measures would impose a disproportionate burden on the employer."126

The UK duty is extensive; employers must consider innovative and wide ranging solutions. ${ }^{127}$ In Archibald v Fife Council, the House of Lords found it might require adjustments such as "adapting the premises, reallocating duties, altering the house, modifying equipment or providing training, interpretation or supervision." ${ }^{128}$ A similar duty to accommodate carers in the workplace could introduce wide ranging adaptions, such as adjusting expectations or sickness policies to reflect the fact that many carers suffer with illhealth. ${ }^{129}$ Horton further argues that introducing a duty of reasonable adjustment for carers would require employers to minimise the negative impact of working part-time. ${ }^{130}$ As women

\footnotetext{
${ }^{123}$ s 20. Busby also considers a similar duty of accommodation in the amended Anti-Discrimination Act 1977 of New South Wales, Australia (s 49T(1)(b)) In this article, I will focus on the UK duty of reasonable adjustment because of the focus upon UK law.

${ }^{124}$ Equality Act 2010, s 20(3)-(4).

125 Ibid. s 20(5).

126 The Employment Equality Directive 2000/78/EC, art 5.

${ }^{127}$ N. Busby A Right to Care? (n 2) 185.

128 [2004] S.C (H.L) 32, [57].

129 Carers UK The State of Caring 2015 (Carers UK, 2015) 8.

${ }^{130}$ R. Horton 'Care-giving and reasonable adjustment in the UK' (n 117) 149.
} 
perform the majority of part-time work, this would challenge gender inequality and decrease the gender pay gap. Such transformative changes demonstrate that the duty of reasonable adjustment could promote the autonomous adjustments carers actually require in the workplace and challenge "an unthinking conformity to existing norms and structures."131

\section{The limitations of a duty of reasonable adjustment}

Busby recognises that a duty of reasonable adjustment falls "somewhat short of the provision of self-standing rights which recognize the social value and related contributions of the individuals they are intended to protect." 132 This is partly because it is reliant upon comparison against the standard worker model, so carers are still identified as different. ${ }^{133}$ Therefore, a duty of reasonable adjustment would not challenge the core of a system that privileges workers without caring responsibilities.

The individualistic nature of each provision further reinforces this. The duty of reasonable adjustment would only bite when the employer knows of the individual's caring responsibilities. ${ }^{134}$ Employers also would only have to respond to the situation and request of each employee. Therefore, although it may encourage some change in some workplaces, it does not require the "broader structural changes within the workplace [which are] needed to make them fully inclusive." 135

Nonetheless, as the duty of reasonable adjustment is only applicable to disabled people in the UK, it has been regarded as extra protection; something better to substitute the anti-

\footnotetext{
${ }^{131}$ O. Smith 'Reconciling Care-giving and Work in Ireland' (n 118) 159.

${ }^{132}$ N. Busby A Right to Care? (n 2) 188.

133 Ibid. 188.

${ }^{134} \mathrm{R}$. Horton 'Care-giving and reasonable adjustment in the UK' (n 117) 148.

${ }^{135}$ Ibid. 148.
} 
discrimination laws. ${ }^{136}$ This is despite the fact that the duty of reasonable adjustment creates more containable rights than discrimination law. The advantage of this narrower scope is that requests may actually be enforced. ${ }^{137}$ The widespread changes that would be dictated by findings of indirect discrimination may make courts less willing to recognise discrimination. However, the prioritisation of the duty of reasonable adjustment has limited both hearings and findings on indirect discrimination. Such hearings could have more fundamentally challenged the workplace model to better accommodate all disabled people. If appropriate cases are not tried as indirect discrimination, the protection afforded to disabled people is undermined. Therefore, although a duty of reasonable adjustment is important, it cannot be prioritised over all other forms of protection.

\section{Failure to promote other social goals}

However, neither recognising carers as a protected characteristic nor extending the duty of reasonable adjustment to carers will challenge the gendered division of labour. Merely enabling men and women equal access to protection for their caring role will not lead to equal uptake because people's actions will remain restricted by moral and socially negotiated views about right and proper behaviour. ${ }^{138}$ Furthermore, rather than waiting for individuals to make use of anti-discrimination legislation, the standard worker model could be more positively challenged by men taking leave. This is because all people would be recognised as potential carers. Accordingly, the workplace would have to change to accommodate all people's caring relationships.

\footnotetext{
${ }^{136}$ C. O’Brien 'Confronting the Care Penalty' (n 119) 18.

${ }^{137}$ Ibid. 25.

${ }^{138}$ A. Barlow, S. Duncan 'Supporting Families? New Labour's Communitarianism and the 'Rationality Mistake': Part 1' (2000) 22 Journal of Social Welfare and Family Law 23, 35.
} 
Busby notes that the EU has restricted competence in implementing legislation with such aims because of its founding objectives as an economic entity, which it cannot detach itself from. ${ }^{139}$ Therefore, the EU has shown a "reluctance to progress measures perceived as overly prescriptive in relation to...the division of labour within families." 140 Nonetheless, the EU has "been a driving force in this area" and has undoubtedly improved the situation of working parents. ${ }^{141}$ This has been evidenced again recently, as the European Commission proposed a Directive on Work Life Balance for Parents and Carers. ${ }^{142}$ The proposed Directive aims to build on and modernise the existing framework to "ensure the implementation of the principle of equality between men and women with regard to labour market opportunities and treatment at work." 143 This is to be improved by strengthening parental leave, ${ }^{144}$ introducing paternity leave, ${ }^{145}$ carers leave, ${ }^{146}$ and flexible working arrangements. ${ }^{147}$ Workers would be protected from discrimination on the grounds that they had applied for or had made use of these entitlements. ${ }^{148}$ Although the Directive is not as revolutionary as Busby's proposal as it fails to recognise caring as a protected characteristic, it is nonetheless "ground-breaking." 149 This is because "it creates concrete individual rights and sends a powerful message. Caring responsibilities have now explicitly been placed on the EU agenda." ${ }^{150}$

\footnotetext{
${ }^{139}$ N. Busby A Right to Care? (n 2) 4.

140 Ibid. 106.

${ }^{141}$ E. Caracciolo di Torella 'An emerging right to care in the EU: a "New Start to Support Work-Life Balance for Parents and Carers" (2017) 18 ERA Forum 187, 188.

$142 \mathrm{https}$ ://eur-lex.europa.eu/legal-content/EN/TXT/HTML/?uri=CELEX:52017PC0253\&from=EN accessed

20.02 .19 .

${ }^{143} \mathrm{https}$ ://ec.europa.eu/info/law/better-regulation/initiatives/com-2017-253 en accessed 20.02.19, 2.

144 Article 4.

145 Article 5.

146 Article 6.

${ }^{147}$ Article 9.

148 Article 11.

${ }^{149}$ E. Caracciolo di Torella 'An emerging right to care in the EU' (n 141) 196.

${ }^{150}$ Ibid. 194.
} 
Caracciolo di Torella further notes that Brexit means that such EU initiatives are more likely to succeed. ${ }^{151}$ This is because the UK has long been a voice of opposition to such reform at EU level. ${ }^{152}$ A pertinent question therefore is whether the UK will follow and build on the EU proposals if they leave (at the time of writing, ${ }^{153}$ not only the final form of Brexit, but even whether there will be one at all, remain unclear). The UK Government, without the limitations of being an economic entity like the EU, could implement progressive legislation promoting social goals. This will be the focus of the next section.

\section{A UK RIGHT TO CARE}

\section{A. Adding carer as a protected characteristic}

A UK right to care would be based around anti-discrimination legislation, requiring employers to accommodate their employees' caring work. ${ }^{154}$ There are a number of possible justifications for anti-discrimination legislation; protecting those who have historically been disadvantaged; tackling social exclusion; or ensuring open access to the workplace. ${ }^{155}$ However, it is widely recognised that such legislation promotes equality. ${ }^{156}$ All these grounds would justify recognising carers as a protected characteristic within anti-discrimination laws. Carers face considerable disadvantages which affect their wellbeing, including physical and mental ill health. ${ }^{157}$ Many also have to reduce their paid working hours to provide care, sometimes having to leave the workplace altogether. ${ }^{158}$ Furthermore, recognising caring as a

\footnotetext{
151 Ibid. 197.

152 Ibid. 189.

${ }^{153}$ March 2019.

${ }^{154}$ N. Busby A Right to Care? (n 2) 11.

${ }^{155}$ Respectively see S. Fredman Discrimination Law (n 120) 138-9; H. Collins 'Discrimination, Equality and Social Inclusion' (2003) 66 The Modern Law Review 16, 21; C. O’Brien 'Confronting the Care Penalty' (n 119) 10.

${ }^{156}$ See S. Fredman Discrimination Law (n 120) 130-139; N. Busby A Right to Care? (n 2) 108; H. Collins

'Discrimination, Equality and Social Inclusion' (n 155) 16.

${ }^{157}$ Carers UK The State of Caring 2015 (Carers UK, 2015) 8.

158 Ibid. 12.
} 
protected characteristic would acknowledge the importance of caring relationships and ensure that they were not affected by "the vagaries of the economy."159

Therefore, any Government would be fully justified adding caring status as a protected characteristic under the Equality Act 2010. This was debated during the drafting process. The then New Labour Government did not enact this for two reasons; firstly, they reasoned that the existing entitlements already available to carers provided the necessary protection, focusing upon the right to request flexible working and the other heads of anti-discrimination law. ${ }^{160}$ The second was that "the role of carer applies more to what a person does, than to what a person is (their innate or chosen characteristics)." ${ }^{\prime 161}$ Therefore, they reasoned that being a carer is not part of "an individual's status or identity."162 However, I argue that neither of these reasons justifies the exclusion of carers as a protected characteristic.

\section{i. Limitations of the existing protection for carers}

Carers may be protected against discrimination on the grounds of sex or disability. Firstly, women's continued association with care has resulted in "workplace policies and practices which disadvantage those who have a care-giving role... [being found] indirectly discriminatory on grounds of sex." ${ }^{\prime 163}$ However, O’Brien notes that a successful claim problematically "requires adopting and evidencing a traditional model of female care roles," rather than challenging these gendered expectations. ${ }^{164}$ Male carers may have been

\footnotetext{
${ }^{159}$ S. Fredman Women and the Law (n 55) 410.

${ }^{160}$ Government Equalities Office The Equality Bill - Government Response to the Consultation (The Stationary Office, 2008) 179.

161 Ibid. 179.

162 N. Busby 'Carers and the Equality Act 2010: Protected Characteristics and Identity' (2011) 11 Contemporary Issues in Law 71, 71.

${ }^{163}$ R. Horton 'Care-giving and reasonable adjustment in the UK' (n 117) 141.

${ }^{164}$ C. O’Brien 'Confronting the Care Penalty' (n 119) 13.
} 
discriminated against if they are treated less well than a female carer, but "this will be of no benefit in an environment where all carers are treated with an equal lack of concern."165 Therefore, protection from sex discrimination does not adequately value caring labour; it fails to recognise the interdependence of caring and paid work.

Carers are also protected from direct discrimination, ${ }^{166}$ and harassment, on the grounds of their association with a disabled person through associative disability discrimination. ${ }^{167}$ However, this also fails to provide adequate protection. Only carers of those who fall within the definition of disabled are protected, which excludes those who are unwell or incapacitated. ${ }^{168}$ Furthermore, these carers are not protected against indirect discrimination, which is the "most common, and so most widely disempowering, type of discriminatory disadvantage encountered by carers." 169 This may also undermine the protection of disabled people, as the disadvantages that carers face in the workplace will inevitably affect the person they care for. ${ }^{170}$ Accordingly, carers are not sufficiently protected by the current anti-discrimination laws. The provision of caring labour "is an independent vector of disadvantage." 171

The New Labour Government finally reasoned that the right to request flexible working was the better way to protect carers, because carers' responsibilities may change. ${ }^{172}$ This argument is problematic for two reasons. Firstly, it suggests that the other protected

\footnotetext{
${ }^{165}$ R. Horton 'Care-giving and reasonable adjustment in the UK' (n 117) 141.

${ }^{166}$ Equality Act 2010, s 13, explained in Explanatory Notes s 59.

167 Ibid. s 26.

${ }^{168} \mathrm{R}$. Horton 'Care-giving and reasonable adjustment in the UK' (n 117) 143.

${ }^{169}$ C. O’Brien 'Confronting the Care Penalty' (n 119) 13.

${ }^{170}$ R. Horton 'Care-giving and reasonable adjustment in the UK' (n 117) 143.

${ }^{171}$ C. O’Brien 'Confronting the Care Penalty' (n 119) 15.

172 Government Equalities Office The Equality Bill (n 160) 180.
} 
characteristics are static; pregnancy evidently changes over time, but so can religion and disability. ${ }^{173}$ Therefore, Busby argues that "it is the status of the individual at the time that the protection is sought that is relevant in assessing the occurrence and extent of the less favourable treatment." ${ }^{174}$ Secondly, as noted earlier, one of the problems with the right to request flexible working is that it leads to a permanent change in the contract. Therefore, it does not accommodate changing caring needs, undermining the New Labour Government's reasoning. ${ }^{175}$ Accordingly, the New Labour Government were not justified in rejecting care as a protected characteristic because the current law does not provide adequate protection to carers.

\section{ii. $\quad$ The problems with considering caring work a choice}

The second reason the New Labour Government rejected including carers as a protected characteristic is arguably even more problematic. Stating "the role of carer applies more to what a person does, than to what a person is," fundamentally misunderstands caring relationships and disregards care ethics. ${ }^{176}$ Caring relationships affect who a person is because people define themselves partly through their relationships; they are relational. ${ }^{177}$ Busby notes that caring is "something you do and something you are."178 Accordingly, the New Labour Government's reasoning was flawed. Their reliance upon the idea that caring is something you do led Busby to rightly conclude that carers were not protected because caring is seen as a choice. ${ }^{179}$

\footnotetext{
${ }^{173}$ N. Busby 'Carers and the Equality Act 2010' (n 162) 88.

174 Ibid. 88.

${ }^{175}$ G. James 'Family-friendly employment law (re)assessed' (n 5) 486.

${ }^{176}$ Government Equalities Office The Equality Bill (n 160) 179.

177 C. Gilligan In a Different Voice (n 87) 156.

${ }^{178}$ N. Busby 'Carers and the Equality Act 2010' (n 162) 86.

179 Ibid. 86.
} 
Disregarding caring as a choice is problematic for two reasons; firstly, some of the other protected characteristics could be characterised as a choice, including pregnancy and religion. ${ }^{180}$ Therefore, "the fact that some aspects of our identity are indeed a matter of personal choice, or can in principle be changed or suppressed, should not be a reason for denying such characteristics the protection of discrimination law." ${ }^{181}$ Secondly, the provision of care can never be considered a personal preference. People's relational sense of self, the expectation of care being provided within the private home and the feelings of guilt which those who cannot provide this care experience, means that this is better identified as a moral imperative. ${ }^{182}$

This section has shown that the New Labour Government was not justified in dismissing being a carer as something a person does, rather than who they are. Accordingly, there was no valid reason for excluding carers from the protected characteristics in the Equality Act 2010. The next section will show that although carers should be recognised within antidiscrimination legislation, enacting this alone will not necessarily achieve transformative changes. Additional legislative support, such as the duty of reasonable adjustment, would still be required.

\section{B. The continued need for duty of reasonable adjustment for carers}

Discrimination laws can have a normative effect, influencing and changing behaviours because they create "a particular standard which is acknowledged and recognized by society." ${ }^{183}$ However, this alone would not ensure that all employers conform. Discrimination

\footnotetext{
${ }^{180}$ S. Fredman Discrimination Law (n 120) 131.

181 Ibid. 131.

${ }^{182}$ M. Eichner 'Square Peg in a Round Hold: Parenting Policies and Liberal Theory' (1998) 59 Ohio State Law Journal 133, 172.

${ }^{183}$ N. Busby A Right to Care? (n 2) 8.
} 
laws are only effective against rogue employers if employees enforce their claims. This requires "certain preconditions: awareness of rights; knowledge of how to enforce them; capacity to claim and willingness to do so."184 The issues in bringing a claim have been exacerbated by the abolishment of almost all civil legal aid. ${ }^{185}$ Furthermore, James notes that the compulsory process of early conciliation through ACAS is a huge time commitment that most parents, and indeed carers, are unable to meet. ${ }^{186}$ Therefore, many carers would be practically unable to enforce their right not to be discriminated against. Without enforcement, employers who discriminate against carers would not be held accountable.

Clearly additional legislative support would be required to realise a right to care in the UK. This would necessitate placing a positive duty upon employers, requiring proactive efforts to accommodate carers within the workplace. ${ }^{187}$ Extending the duty of reasonable adjustment to carers would enforce such a positive duty as Busby suggested at EU level. It would cover all caring relationships and could achieve transformative change. This is partly because employers would have to justify their reasons for refusing requests. Furthermore, employers would have to be mindful of the effects of part-time work. ${ }^{188}$ I noted earlier that this would have a narrower application than discrimination law, responding to individual requests, but that this may lead to requests actually being enforced. ${ }^{189}$ The enforcement of some requests may encourage self-directed change across the workplace.

\footnotetext{
${ }^{184}$ L. Dickens 'The Coalition Government's Reforms to Employment Tribunals and Statutory Employment Rights - Echoes of the Past' (2014) 45 Industrial Relations Journal 234, 238.

${ }^{185}$ G. James 'Family-friendly employment law (re)assessed' (n 5) 488.

186 Ibid. 489.

${ }^{187}$ O. Smith 'Reconciling Care-giving and Work in Ireland' (n 118) 167.

${ }^{188}$ N. Busby A Right to Care? (n 2) 187.

${ }^{189}$ C. O’Brien 'Confronting the Care Penalty' (n 119) 25.
} 
However, the UK courts have refused to recognise the duty of reasonable adjustment for carers. In Hainsworth v Ministry of Defence v Equality and Human Rights Commission, a mother argued that a move to the UK to educate her disabled child would have amounted to reasonable accommodation under article 5 of the Employment Equality Directive. ${ }^{190}$ She could not rely on the Equality Act 2010 because she was not an employee. The EHRC, intervening as a third party, highlighted the relational nature of care, recognising that a failure to accommodate carers will detrimentally affect both the carer's work and the dependent person. ${ }^{191}$ However, the Court of Appeal rejected this argument and followed a strict interpretation of the law, limiting protection to the disabled person. ${ }^{192}$ In disregarding the EHRC's intervention, the court problematically ignored the practical realities of caring labour and denied disabled people protection in practice.

Furthermore, the European Court of Human Rights (ECtHR) has stated that the UK legislation "would be rendered meaningless or could prove to be disproportionate if...not limited to disabled persons only." 193 This is because the duty aimed "specifically to facilitate and promote the integration of disabled people into the working environment and, for that reason, can only relate to disabled people."194

Yet the ECtHR has extended the duty of reasonable adjustment to include grounds of religion and belief. In Eweida and others $v U K$, the ECtHR found that individual as well as group disadvantages caused by employment practices or conditions which restrict employees' freedom of religion require justification. ${ }^{195}$ This suggests that employers have a duty to

\footnotetext{
190 2000/78/EC.

191 [2014] EWCA Civ 763, [3].

192 Ibid. [25].

${ }^{193}$ Coleman v. Attridge Law and Steve Law C-303/06 [2008] ECR I-5603, [42].

194 Ibid. [42].

195 [2013] IRLR 231, [83].
} 
accommodate individuals' religious beliefs reasonably within the workplace. However, the Court of Justice of the European Union recently found that banning all religious, political or philosophical symbols in the workplace is not discriminatory, which could undermine Eweida. ${ }^{196}$ Nonetheless, the Equality and Human Rights Commission's (EHRC) current guidance for UK employers more closely reflects the ECtHR decision, stating that when dealing with a request to modify workplace conditions for religious purposes, employers must do more than act reasonably. ${ }^{197}$ To show that they have acted proportionately, the EHRC suggests that employers should demonstrate there is no "alternative way of achieving the aim of the rule or policy which doesn't have the discriminatory impact, or which lessens it." 198 Therefore, the UK clearly have taken a step towards extending the duty of reasonable adjustment, which demonstrates that it does not have to be limited to disabled people. ${ }^{199}$

This extension of the duty of reasonable adjustment to grounds of religion or belief has been regarded as inappropriate because it is different to disability. "The rationale for the duty is that the disability actually impairs the individual's ability to work," which Pitt suggests is different to religion. ${ }^{200}$ For example, Eweida's claim that the UK law had failed to protect her right to manifest her religion because she was unable to work with a Christian cross necklace visible. This claim was upheld despite the fact that she did work for a period with her necklace concealed. ${ }^{201}$ Secondly, religion and disability are different because "disabilities vary enormously in kind and degree." ${ }^{202}$ A final reason the extension to religion has been

\footnotetext{
${ }^{196}$ Case C-157/15 Samira Achbita and Centrum voor gelijkheid van kansen en voor racismebestrijding v G4S Secure Solutions NV.

${ }^{197}$ Equality and Human Rights Commission Religion or Belief: A Guide to the Law (Equality and Human Rights Commission, 2016) 9.

198 Ibid. 8.

${ }^{199}$ G. Pitt 'Taking Religion Seriously' (2013) 42 Industrial Law Journal 398, 404.

200 Ibid. 405.

201 [2013] IRLR 231, [12].

${ }^{202}$ G. Pitt 'Taking Religion Seriously' (n 199) 405.
} 
seen as problematic is that "many religions have teachings that are extremely offensive to some groups." 203 Again, this was demonstrated in Eweida, as two of the four applications considered were from employees who wanted to deny equal treatment to same-sex couples. ${ }^{204}$

Yet it should be acknowledged that these concerns are not relevant to extending the duty of reasonable adjustment to carers. Unlike religion, it is widely acknowledged that caring responsibilities impair people's ability to participate in paid work. ${ }^{205}$ Also, caring relationships vary so they cannot be fitted into a standard model. Therefore, "disability and care are on a continuum of shared experience." ${ }^{206}$ Caring practices are also unlikely to be considered offensive as all people require them at some point. One notable exception is breastfeeding, which research suggests that many people perceive as "largely negative, sexual, something that animals do, and worthy of disgust." ${ }^{207}$ However, breastfeeding is the primary biological function of female breasts and it "is acknowledged to be the optimal way both of feeding and caring for young infants." ${ }^{208}$ Arguments suggesting breastfeeding is offensive cause grave injustices to women and children. These are not relevant to extending the duty of reasonable adjustment to carers. Indeed, accommodating breastfeeding in the workplace would be a key way of enabling women to return and share childcare with others.

Therefore, there is no justification for failing to extend the duty of reasonable adjustment to carers. The extension to grounds of religion shows that it is possible to extend the

\footnotetext{
${ }^{203}$ R. McCrea 'Religion in the Workplace: Eweida and Others v United Kingdom' (2014) 77 Modern Law Review 277, 281.

204 [2013] IRLR 231, [23] and [31].

205 S. Fredman 'Reversing Roles: Bringing Men into the Frame' (2014) 10 International Journal of Law in Context 442, 442.

${ }^{206}$ C. O’Brien 'Confronting the Care Penalty' (n 119) 23.

${ }^{207}$ M. Acker 'Breast is Best... But Not Everywhere: Ambivalent Sexism and Attitudes Towards Private and Public Breastfeeding' (2009) 61 Sex Roles 476, 479.

${ }^{208}$ M. Latham 'Breastfeeding - A Human Rights Issue?' (1997) 5 The International Journal of Children's Rights 397, 397.
} 
protection. Furthermore, the proposed extension to carers is more justifiable because carers and disabled people have more similar workplace experiences, and this would not involve accommodating potentially offensive requests. Some may be strongly opposed to accommodating carers in the paid workplace because they conceive caring as a choice. However, as I argued earlier, not only is it inappropriate to conceive the provision of care as a choice, it is vital that carers are supported to achieve justice.

Extending the duty of reasonable adjustment to carers would also effectively replace the problematic right to request flexible working. The duty of reasonable adjustment would enable carers to change their working hours or work at home, like the right to request flexible working, but the entitlement would be much stronger; employers would be unable to refuse a reasonable request. Therefore, employers would be held to a higher standard. Carers would further benefit from the flexibility provided by the duty of reasonable adjustment. This would enable carers to accommodate the fluctuating needs within a caring relationship, rather than mandating permanent change like the right to request flexible working. Furthermore, requests would not be limited to changing working hours; criterions that put carers at a substantial disadvantage could also be challenged. ${ }^{209}$ This would produce more transformative results as employers would have to be conscious about the effects of caring, such as how it affects physical and mental health. Therefore, Horton argues that reasonable adjustment might require changing working policies, such as sickness leave, to ensure that carers are not penalised. ${ }^{210}$ Finally, the duty of reasonable adjustment, unlike the right to request flexible working, may serve to challenge the negative consequences of part-time work, which often

\footnotetext{
${ }^{209}$ Equality Act 2010, s 20(3).

${ }^{210} \mathrm{R}$. Horton 'Care-giving and reasonable adjustment in the UK' (n 117) 149.
} 
includes an immediate and significant reduction in wages. ${ }^{211}$ Therefore, the duty of reasonable adjustment would benefit carers, negating the right to request flexible working.

Extending the duty of reasonable adjustment to protect carers would be an important step towards embracing the ethic of care and this section has shown that it could be achieved in the UK. However, as noted earlier, gender inequality and the standard worker model would remain unchallenged. The duty would therefore need to be supplemented by a substantive body of reconciliation legislation, consolidated by the right to care. This is the focus of the final section.

\section{Using the overarching right to care to eradicate legislative gaps}

As noted earlier, Busby argues that one of the key benefits of a right to care is that it would consolidate existing laws affecting carers and provide the evaluative space to determine how to promote carers' wellbeing. This would also be a key advantage in the UK. This is because, much like the EU laws, the UK body of reconciliation legislation has not developed as part of a unified strategy. Instead different Governments have sought to implement their own agenda. Furthermore, some of the legislation has been implemented as a result of EU Directives. This means that there are gaps in the body of legislation. By unifying the various strands of legislation under a general right to care, these existing gaps would be more readily identified and would justify the introduction of legislation to reduce or remove them. Such changes would better value caring work. Two clear gaps are apparent from the earlier discussion of the body of legislation; gender inequality and the standard worker model remain uncontested. Both of these could be challenged by care centric reconciliation legislation which actively encourages all people to take leave, especially men.

${ }^{211}$ C. Lyonette et al. Quality Part-time Work (n 83) 8-9. 
Challenging the standard worker model would require a number of changes. Firstly, the eligibility requirements would need to be removed to include non-employees and those without the requisite commitment to the relevant employer. Employers would have to accommodate all workers' use of the various entitlements. This would recognise that caring labour is equally as important as paid work. Secondly, challenging the standard worker model would require that the leave entitlements would be available more flexibly, on a part-time basis.

Flexible leave would also challenge gender inequality, as it would make men more likely to take leave. ${ }^{212}$ However, more would be needed; men could be encouraged to care through the leave entailments available to parents. To encourage men's uptake of leave, a period should be reserved for each parent on a non-transferable, use it or lose it basis. ${ }^{213}$ The success of this would also require that the level of payment is increased. The " fall back' of relying solely on the traditional, "tried and tested' maternity leave option," should also be challenged. ${ }^{214}$ This would require that maternity leave distinguish pregnancy, which is only experienced by women, from parenthood, which is gender neutral. Research suggests that most mothers recover in six to eight weeks from childbirth. ${ }^{215}$ Therefore, after eight weeks, leave should be made available to both parents. These changes should encourage more men to take leave. Once that happens, men may be more inclined to provide care in other

\footnotetext{
${ }^{212}$ M. Kilkey 'New Labour and Reconciling Work and Family Life: Making it Fathers' Business' (2006) 5 Social Policy and Society 167, 169.

${ }^{213}$ See J. Gornick, M. Meyers 'Creating Gender Egalitarian Societies: An Agenda for Reform' (2008) 36 Politics and Society $313,331$.

${ }^{214}$ G. James 'Family-friendly employment law (re)assessed' (n 5) 498.

${ }^{215}$ P. Foubert The Legal Protection of the Pregnant Worker in the European Community (Kluwer International Law, 2002) quoted in I. Robeyns 'Should Maternity Leave be Expanded?' (2012) 6 Ethics and Social Welfare 206, 208.
} 
relationships, as they may become more relational. Once men are participating more widely within caring relationships, the duty of reasonable adjustment would support them as carers.

Childcare is not only important in the first year of a child's life, yet the current body of legislation has a "myopic focus" on a child's first year; unpaid parental leave is not effective enough to acknowledge the long term commitment that childcare entails. ${ }^{216}$ The duty of reasonable adjustment would provide some support in this regard, especially as the

adjustments do not have to lead to permanent change. Nonetheless, there may be times when workers can anticipate that they are going to need to take leave, such as after an operation or in school holidays. Parental leave should be modified to include payment and should be available more flexibly to fill this gap.

Finally, in addition to the support afforded by the duty of reasonable adjustment, those caring for dependent adults may also require access to leave in labour intensive periods, such as after a planned operation. Therefore, a gap would remain that should be filled by an entitlement for all carers to a reasonable period of leave, mirroring an improved parental leave entitlement. Such an entitlement should support each caring relationship.

\section{CONCLUSION}

UK reconciliation legislation currently fails to value care work. Instead, the legislation remains focused primarily upon the importance of paid work. In this article, I have drawn upon James' work to show that this would be challenged if the legislation better reflected the ethic of care. This is primarily because it would elevate the status of carers and caring labour, recognising that caring relationships are universal and a positive element in all our lives.

${ }^{216}$ S. Fredman Women and the Law (n 55) 196. 
This article has shown that a right to care is one way that care ethics could be implemented into UK reconciliation legislation to challenge its substantive problems. A right to care would lead to transformative change because of the focus upon promoting fundamental change, rather than incremental legislative modifications. Furthermore, it would create an evaluative space in which the relative successes and weaknesses of all the relevant entitlements which affect carers could be analysed. This would highlight any gaps which need to be filled. By requiring proactive steps to be taken to accommodate carers and fill these gaps, genuine workplace change would be promoted.

Without the protection guaranteed by the EU, Brexit means that it is even more important that UK legislators support caring work. The proposed Directive on Work Life Balance for Parents and Carers shows that the EU remains committed to promoting carers' rights in the workplace, and if implemented, will leave post-Brexit UK lagging behind in terms of workers' rights. This could and should provide the impetus for legislative change in the UK, reflecting the right to care. However, Brexit may also reduce the likelihood of such a right being implemented in the UK. As the Government prepares for a period of uncertainty for the UK economy in light of the decision to leave the $\mathrm{EU},{ }^{217}$ it is likely that reconciliation legislation will be "shelved or diluted" as priorities shift towards protecting businesses. ${ }^{218}$ Furthermore, the UK has always been an awkward partner in the EU's social legislation, often undermining attempts to improve it. ${ }^{219}$ Therefore, the EU post-Brexit may make better progress in this area, which the UK may choose not to follow. One thing is certain as the UK enters this period of uncertainty; caring work and carers' responsibilities are not becoming

\footnotetext{
${ }^{217}$ HM Treasury Autumn Statement 2016 (Crown, 2016) 1.

218 G. James 'Family-friendly employment law (re)assessed' (n 5) 479.

219 See E. Caracciolo di Torella 'An emerging right to care in the EU' (n 141) 189. 
less important. After all, care needs are universal; all people require care at different points in their lives. It is vital that UK reconciliation legislation recognises this if genuine workplace change is to be achieved. 